\title{
A Bipartite Begomovirus Infecting Boerhavia erecta (Family Nyctaginaceae) in the Dominican Republic Represents a Distinct Phylogenetic Lineage and has a High Degree of Host Specificity
}

\author{
Tomas A. Melgarejo, ${ }^{1,2}$ Maria R. Rojas, ${ }^{1}$ and Robert L. Gilbertson ${ }^{1, \dagger}$ \\ ${ }^{1}$ Department of Plant Pathology, University of California, Davis, One Shield Ave., CA 95616, U.S.A. \\ ${ }^{2}$ Departamento de Fitopatologia, Universidad Nacional Agraria La Molina, Av. La Molina s/n La Molina, Lima, Peru \\ Accepted for publication 15 April 2019.
}

\begin{abstract}
Boerhavia erecta plants in and around agricultural fields in the Azua Valley of the southeastern Dominican Republic often show striking golden mosaic symptoms. Leaf samples from $B$. erecta plants showing these symptoms were collected in 2012 and 2013, and PCR tests with degenerate primers revealed begomovirus DNA-A and DNA-B components. The complete sequences of the DNA-A and DNA-B components of four isolates show a high degree of sequence identity $(>96 \%)$ and a genome organization typical of New World (NW) bipartite begomoviruses. Sequence comparisons and phylogenetic analyses revealed that these isolates composed a new phylogenetic lineage of NW bipartite begomoviruses. The most closely

which the name Boerhavia golden mosaic virus (BoGMV) is proposed. Infectious cloned BoGMV DNA-A and DNA-B components induced golden mosaic symptoms in agroinoculated $B$. erecta plants, thereby fulfilling Koch's postulates for this disease. Agroinoculation and mechanical transmission experiments revealed that BoGMV has an unusually narrow host range, limited to members of the family Nyctaginaceae and not including the permissive host Nicotiana benthamiana. The inability of BoGMV to infect $N$. benthamiana was due to a deficiency in cell-to-cell movement but not to a unique amino acid residue in the movement protein.
\end{abstract} related begomovirus is Merremia mosaic virus, a weed-infecting species from Puerto Rico. Because DNA-A sequence identities are well below the $91 \%$ threshold, these isolates represent a new begomovirus species, for
Keywords: Bemisia tabaci, etiology, geminivirus, Mirabilis expansa, viral evolution, virology
Members of the family Geminiviridae have a circular singlestranded DNA genome encapsidated in twinned quasi-isometric virions measuring approximately 18 to $30 \mathrm{~nm}$ (Zerbini et al. 2017). This family has been recently expanded to nine genera: Becurtovirus, Begomovirus, Curtovirus, Eragrovirus, Mastrevirus, Topocuvirus, Turncurtovirus, Capulavirus, and Grablovirus (Varsani et al. 2017). Members of the genus Begomovirus are transmitted by the whitefly species complex Bemisia tabaci, and constitute the largest number of species in the family Geminiviridae (approximately 90\%). Collectively, begomoviruses infect a wide range of cultivated and noncultivated dicotyledonous plants, and cause numerous economically important diseases of fiber and vegetable crops (Rojas et al. 2018). Begomovirus diseases occur in tropical and subtropical regions throughout the world, and their spread and emergence has been mediated by the B. tabaci supervector (Gilbertson et al. 2015). Phylogenetic analyses of begomoviruses have revealed a phylogeographic distribution, which reflects ancient linages that likely emerged before continental drift. Thus, the majority of begomoviruses in the Old World (OW) have a monopartite genome of approximately $2.8 \mathrm{~kb}$ and are commonly associated with different types of satellite and satellitelike DNAs (Zhou 2013). In contrast, most species from the New World (NW) have a bipartite genome composed of DNA-A and DNA-B components that are each approximately $2.6 \mathrm{~kb}$. The DNA-A component of bipartite begomoviruses is homologous to the genomic DNA of monopartite begomoviruses (Gilbertson et al.

${ }^{\dagger}$ Corresponding author: R. L. Gilbertson; rlgilbertson@ucdavis.edu

*The $e$-Xtra logo stands for "electronic extra" and indicates that six supplementary figures and three supplementary tables are published online.

The author(s) declare no conflict of interest.

(C) 2019 The American Phytopathological Society
2015; Hanley-Bowdoin et al. 2013; Rojas et al. 2005). The sequences of the DNA-A and DNA-B components of bipartite begomoviruses are different except for an approximately 150- to 200-nucleotide (nt) common region (CR), which has high sequence identity $(\geq 90 \%)$ between cognate components of a species. The CR contains the viral origin of replication, including a highly conserved stem-loop structure containing the invariant nonanucleotide TAATATT $\downarrow$ AC sequence, which is the nicking site for initiation of rolling-circle replication of the viral genome (Hanley-Bowdoin et al. 2013). Also contained within the $\mathrm{CR}$ are high affinity binding sites for interaction with the replicationassociated protein (Rep) and maintenance of the bipartite genome, and cis elements (TATA- and G-box) involved in virus replication and transcription (Argüello-Astorga and Ruiz-Medrano 2001; Gutierrez 1999; Hanley-Bowdoin et al. 1999, 2013).

In addition to infecting crop plants, begomoviruses infect a diversity of weed species, often inducing striking golden or yellow mosaic symptoms in leaves of infected plants. In South and Central America, numerous bipartite NW begomovirus species have been reported infecting weed species in the families Asteraceae, Capparaceae, Convolvulaceae, Euphorbiaceae, Fabaceae, Malvaceae, and Solanaceae (Barreto et al. 2013; Blawid et al. 2013; da Silva et al. 2011; Ferro et al. 2017; Fiallo-Olivé et al. 2017; Hernández-Zepeda et al. 2007b; Mar et al. 2017; Melgarejo et al. 2015; Melo et al. 2016; Nascimento et al. 2016; Passos et al. 2017; Pinto et al. 2016; Romay et al. 2016; Stewart et al. 2014; Tavares et al. 2012). These weed-infecting begomoviruses also show a high level of genetic diversity (Lima et al. 2013; Melgarejo et al. 2015; Rocha et al. 2013; Sobrinho et al. 2014).

It has long been hypothesized that begomoviruses infecting noncultivated plants serve as (i) inoculum sources for cropinfecting begomoviruses and (ii) progenitors for the evolution and emergence of such viruses (Barreto et al. 2013; Martínez-Ayala et al. 2014; Sánchez-Campos et al. 2013). Several lines of evidence support the latter hypothesis. First, molecular studies have shown 
that weed- and crop-infecting begomoviruses are usually genetically distinct. Second, there are relatively few reports of weedinfecting begomoviruses extensively infecting crop plants and causing economic losses (Inoue-Nagata et al. 2016), although host range studies have demonstrated that some weed-infecting begomoviruses can also infect crop plants (Barbosa et al. 2011; Blawid et al. 2013; Melgarejo et al. 2015; Pramesh et al. 2013; Tahir et al. 2015). Third, the well-established phenomenon of local evolution of most crop-infecting begomoviruses is more consistent with weed-infecting begomoviruses serving as progenitors of these crop-infecting viruses (Idris et al. 2019; Melgarejo et al. 2013; Zhou et al. 2008). Together, these findings indicate the importance of host adaptation of begomoviruses, and help explain the high degree of sequence divergence between weed- and crop-infecting viruses (Ambrozevicius et al. 2002; Barboza et al. 2018; Lima et al. 2013; Silva et al. 2012).

Boerhavia erecta is an annual plant in the family Nyctaginaceae and is native to the United States, Mexico, Central America, and western South America (https://plants.sc.egov.usda.gov/java/). It is now found worldwide in tropical and subtropical regions, including Africa and Asia, where it is considered an invasive weed species (Chen and Wu 2007; Struwig and Siebert 2013). In the Azua Valley of the southeastern Dominican Republic, B. erecta is a common weed in and around agricultural fields and disturbed areas (Bastidas et al. 2008). In this region, it is not uncommon to find $B$. erecta plants with striking golden mosaic symptoms, suggestive of begomovirus infection. Similar symptoms in B. coccinea plants in Mexico were associated with infection by a distinct NW begomovirus species, Boerhavia yellow spot virus (BoYSV) (Hernández-Zepeda et al. 2007a).

In the present study, we describe the biological and molecular properties of a new bipartite begomovirus associated with golden mosaic symptoms in B. erecta plants in the Azua Valley of the Dominican Republic, for which the name Boerhavia golden mosaic virus (BoGMV) is proposed. Isolates of BoGMV constituted a distinct and strongly supported cluster, revealing a new lineage of NW begomoviruses. Full-length infectious DNA-A and DNA-B clones of BoGMV induced golden mosaic symptoms in agroinoculated $B$. erecta plants, fulfilling Koch's postulates for this disease. We further show that BoGMV has a very narrow host range, restricted to members of the family Nyctaginaceae and not including the permissive host, Nicotiana benthamiana. Finally, pseudorecombination (PR), replication, and mutational analyses were used to investigate the BoGMV-host interactions.

\section{MATERIALS AND METHODS}

Virus source, sample preparation, DNA extraction, and detection of begomovirus DNA. As part of surveys to identify potential reservoir hosts of Tomato yellow leaf curl virus in the Azua Valley, leaf samples with golden mosaic symptoms were collected from $B$. erecta plants from four locations in and around processing tomato fields in 2012 and 2013. Sample B1 was collected in March 2012, sample B2 was collected in February 2013, and samples B3-1 and B3-2 were collected in June 2013. In the Dominican Republic, sap was prepared from leaf tissue (approximately $3.0 \mathrm{~g}$ ) by grinding in plastic bags containing approximately $3.0 \mathrm{ml}$ of LYL1 buffer (Agdia, Elkhart, IN, U.S.A.), and Agdia absorption strips were inserted into the sap for $30 \mathrm{~s}$, which allowed the absorbent pad to become saturated. The strips were allowed to dry overnight at room temperature, and then transported to the University of California at Davis (UC Davis). Total DNA was extracted from the dried plant sap on the absorbent pads according to the method of Dellaporta et al. (1983).

Begomovirus DNA-A and DNA-B components were detected by PCR with the degenerate primer pairs PAL1v1978/PAR1c496 and PCRc1/B1200F (Inoue-Nagata et al. 2004; Rojas et al. 1993), respectively. PCR-amplified DNA-A and DNA-B fragments were purified with the QIAquick gel extraction kit (Qiagen, Germantown, MD, U.S.A.) and directly sequenced with the PAL1v1978 and B1200F primers, respectively, at the UC Davis DNA Sequencing Facility.

Cloning of full-length begomovirus DNA components. Rolling circle amplification (RCA) with $\Phi$-29 DNA polymerase (TempliPhi; GE Healthcare, Piscataway, NJ, U.S.A.) was used to generate linear double-stranded concatemers of begomovirus DNA (Inoue-Nagata et al. 2004). The resulting RCA products were digested with various restriction enzymes to identify single sites in each component (i.e., that generated linear approximately $2.6-\mathrm{kb}$ fragments). Putative full-length DNA-A and DNA-B fragments were obtained with EcoRI and NdeI, respectively. The resulting putative monomeric components were gel purified and cloned into pSL1180 (Promega Corp., Madison, WI, U.S.A.). Recombinant plasmids were identified by restriction enzyme digestion and DNA sequence analyses.

Sequencing and phylogenetic analyses. Sequences of the putative full-length DNA-A and DNA-B components were determined at the UC Davis DNA Sequencing Facility, and analyzed with the Vector NTI Advance software (Invitrogen, Carlsbad, CA, U.S.A.). Pairwise nucleotide sequence alignments were performed with Muscle within the species demarcation tool (SDT) v.1.2 (Muhire et al. 2014). SDT analysis with full-length DNA-A component sequences was then used to determine the relationship of the begomovirus isolates from $B$. erecta from the Dominican Republic with (i) the 18 most closely related begomoviruses identified by a BLASTn search and (ii) selected species representing the four major lineages of NW bipartite begomoviruses: Abutilon mosaic virus, Brazilian begomoviruses, Squash leaf curl virus (SLCuV), and Bean golden yellow mosaic virus (BGYMV). Comparisons were also made with sequences of the full-length DNA-B components, the $\mathrm{CR}$, and individual open reading frames (ORFs) from both components with those of the 11 most closely related begomoviruses.

For phylogenetic analyses, we included complete DNA-A and DNA-B sequences of begomovirus isolates from $B$. erecta leaf samples B1, B2, B3-1, and B3-2; the 18 most closely related begomoviruses; and selected species representing the four lineages of NW bipartite begomoviruses. In this analysis, we also included the complete DNA-A sequence of BoYSV from Mexico (there is no DNA-B component sequence available). Nucleotide sequence alignments were performed with the Muscle program in MEGA v.7 (Kumar et al. 2016), and the aligned sequences were edited and exported as nexus files. Phylogenic trees were constructed using Bayesian inference performed with MrBayes v.3.2.4 (Ronquist et al. 2012). The best-fit model of nucleotide substitution was determined with the program jModelTest v.2.1 (Darriba et al. 2012). The Bayesian analysis was carried out by running $2.5 \mathrm{M}$ generations, and trees were sampled every 100th generation, resulting in 25,000 trees. After discarding the first $20 \%$ of samples as burn-in, the remaining 20,000 trees were used for calculating posterior probabilities (PPs) in the consensus tree. Trees for the DNA-A and DNA-B sequences were generated in FigTree v.1.4.2 (http://tree.bio.ed.ac.uk/software/figtree) and rooted with the DNA-A and DNA-B components, respectively, of the OW bipartite begomovirus Tomato leaf curl New Delhi virus (ToLCNDV).

Non-tree-like relationships indicative of recombination were assessed in the data set of DNA-A component sequences used in the phylogenetic analysis by the construction of a phylogenetic network with the Neighbor-Net method (Bryant and Moulton 2004) and the Pairwise Homoplasy Index (PHI) test (Bruen et al. 2006) implemented in the program SplitsTree v.4.14.4 (Huson and Bryant 2005). Recombination events, breakpoints, and parental sequences were also assessed in this DNA-A data set with the Recombination Detection Program (RDP) v. 4.46 (Martin et al. 2015), with default settings and a Bonferroni-corrected $P$ value cutoff of 0.001 . To minimize the probability of false positives, only 
recombination events detected with all eight methods implemented in RDP were considered likely to be real.

Production of multimeric clones and an agroinoculation system. To determine infectivity of the cloned DNA-A and DNA-B components of the B1 isolate (hereafter referred to as B1), multimeric clones were generated in the pCAMBIA1300 binary vector (Hajdukiewicz et al. 1994). For the DNA-A component, an approximately 1.8-kb EcoRI-Bam HI fragment containing the CR was cloned into pCAMBIA1300 to generate a 0.7-mer pC-B1-A0.7. The full-length monomer (EcoRI fragment) was then cloned into the EcoRI site of pC-B1-A0.7 to generate the 1.7-mer pC-B1-A1.7. For the DNA-B component, an approximately 1.8-kb NdeI-XbaI fragment containing the CR was cloned into pSL1180 to generate a 0.7-mer pSL-B1-B0.7. The full-length monomer (NdeI fragment) was then cloned into the NdeI site of pSL-B1-B0.7 to generate the 1.7-mer pSL-B1-B1.7. This plasmid was then digested with EcoRI and HindIII, and the resulting fragment with the 1.7-mer was cloned into pCAMBIA1300 to generate pC-B1-B1.7. Recombinant plasmids having the multimeric clones were identified by restriction enzyme digestion and transformed into competent Agrobacterium tumefaciens cells (strain C58C1) with the freeze-thaw method (Wise et al. 2006).

Determination of infectivity and host range. Infectivity of the cloned B1 multimeric DNA components was initially assessed by agroinoculation of $B$. erecta seedlings ( 2 weeks old) and $N$. benthamiana plants at the three- to five-leaf stage ( 3 weeks old). Plants were inoculated with a mixture of cell suspensions of A. tumefaciens strain (optical density at $600 \mathrm{~nm}=1.0$ ) with the DNA-A and DNA-B multimeric clones of B1 by needle puncture inoculation of the stem just beneath the shoot apex.

Mechanical (sap) inoculation of $B$. erecta and $N$. benthamiana plants was performed as previously described (Gilbertson et al. 1991). Sap was prepared from leaf tissue of 4-week-old B. erecta and $N$. benthamiana plants.

Host range determination was performed by agroinoculation and mechanical inoculation of $N$. tabacum 'Samsun', $N$. benthamiana, N. glutinosa, Datura stramonium, Solanum lycopersicon 'Glamour', Capsicum annuun 'Cayenne long', Phaseolus vulgaris 'Topcrop', Cucurbita pepo 'Small sugar', Chenopodium quinoa, C. amaranticolor, and Ocimum basilicum seedlings. In addition to B. erecta, two species in the family Nyctaginaceae, Mirabilis jalapa and $M$. expansa, were also inoculated.

Inoculated plants were maintained in a growth chamber and monitored on a daily basis, with the final recording of disease incidence and symptoms done at 21 to 24 days postinoculation (dpi). For selected symptomatic and all symptomless plants, the presence of DNA-A and DNA-B components in newly emerged (noninoculated) leaves was determined by PCR with primers specific for each component (Supplementary Table S1).

PR experiments. $N$. benthamiana plants were agroinoculated with mixtures of cell suspensions of A. tumefaciens strains with multimeric clones of the DNA-A and DNA-B components of Jatropha mosaic virus (JMV) Az-4 strain (this strain was used throughout the study) (Melgarejo et al. 2015), and the B1 multimeric DNA-A and DNA-B clones. The negative control consisted of plants agroinoculated with an A. tumefaciens strain with the empty pCAMBIA1300 vector (EV). All inoculated plants were maintained in a growth chamber, and symptoms were recorded at 21 to $24 \mathrm{dpi}$. The presence of viral DNA components in newly emerged leaves of agroinoculated plants was evaluated as described above with component-specific primers.

Leaf disk replication assays. The replication of the DNA-A and DNA-B components of B1 was assessed in B. erecta and $N$. benthamiana leaf disks as described by Kon et al. (2009). Total DNA was extracted from agroinfiltrated leaf patches 5 days after agroinfiltration (daa) and from newly emerged leaves 15 days later. Approximately $2.5 \mu \mathrm{g}$ of total DNA was fractionated in $1.0 \%$ agarose gels in Tris-borate-EDTA buffer and transferred to
Hybond-N+ nylon membranes (Amersham Pharmacia, Piscataway, NJ, U.S.A.). Blots were hybridized with specific probes for B1: an approximately 2.0-kb DNA-A fragment spanning nucleotides 174 to 2,183, and an approximately 1.9-kb DNA-B fragment spanning nucleotides 163 to 2,051. DNA probes were labeled with digoxigenin (DIG) and the random primed labeling technique (Sigma Aldrich, Deisenhofen, Germany).

Replication of the PRs was assessed in infiltrated $N$. benthamiana leaf disks. In this case, blots were hybridized with JMV- or B1specific DNA-A probes, nucleotides 235 to 2,140 for JMV DNA-A and as previously described for B1; or DNA-B-specific probes, nucleotides 125 to 2,051 for JMV DNA-B and as previously described for B1. In these experiments, the amount of DIG-labeled DNA probes was standardized based upon quantification of labeling efficiency according to the manufacturer's instructions.

Cell-to-cell movement assays. Movement of begomovirus DNA-A and DNA-B components outside of infiltrated patches in $N$. benthamiana leaves was assessed by RCA and restriction enzyme digestion. $N$. benthamiana leaves were infiltrated with A. tumefaciens strains with the multimeric DNA-A and DNA-B components and leaf disks of $0.7-\mathrm{cm}$ diameter were collected from inside and outside (approximately $5 \mathrm{~mm}$ away) of the infiltrated leaf patch at 4, 7, and 10 daa. Total DNA extraction and RCA reactions were performed as previously described. The RCA products were digested with BamHI (B1) or BsrBI (JMV). For B1, BamHI digestion produces an approximately 2.6-kb DNA-A fragment and approximately $0.6-$ and 2.0-kb DNA-B fragments, respectively, whereas, for JMV, BsrBI digestion produces an approximately 2.6-kb DNA-A fragment and approximately 1.1- and approximately $1.5-\mathrm{kb}$ DNA-B fragments, respectively.

Mutational analysis. Mutations were introduced into the $\mathrm{BC} 1$ ORF, which encodes the movement protein (MP), of the DNA-B components of $\mathrm{B} 1$ and JMV. The recombinant plasmids pC-B1$\mathrm{B} 1.7$ and pC-Az-4-B1.6 (Melgarejo et al. 2015) were used as templates for site-directed mutagenesis with phosphorylated primers. The mutations were double-nucleotide substitutions (AGT to GTT at nucleotides 1,305 and 1,306 for B1 or GTT to AGT at nucleotides 1,304 and 1,305 for JMV). This resulted in Thr260 to Asn260 and Asn260 to Thr260 substitutions in the MPs of B1 and JMV, respectively. PCR was performed according to the protocol of the Q5 High-Fidelity DNA polymerase (New England BioLabs, Ipswich, MA, U.S.A.). Following mutagenesis, the PCRamplified DNA components were self ligated; digested with NdeI or ApaI for B1 or JMV, respectively; and cloned into NdeI- or ApaIdigested pSL1180. Recombinant plasmids were recovered, and the presence of the introduced mutation (as well as the lack of any other introduced mutations) was verified by sequence analysis. Monomers confirmed to have the mutations were used to generate multimeric clones for agroinoculation. For the B1 DNA-B Thr260Asn mutant, the multimeric clone was constructed as previously described to generate the $\mathrm{pC}-\mathrm{B} 1-\mathrm{B} 1.7$ mutant construct; and, for the JMV DNA-B Asn260Thr mutant, an approximately 1.5-kb ApaI-NdeI fragment containing the CR was cloned into pSL1180 to generate a 0.6-mer pSL-Az-4-B0.6. The full-length monomer (ApaI fragment) was then cloned into the ApaI site of pSL-Az-4-B0.6 to generate the 1.6-mer pSL-Az-4-B1.6. This plasmid was then digested with EcoRI and HindIII, and the resulting fragment with the 1.6-mer was cloned into pCAMBIA1300 to generate the pC-Az-4-B1.6 mutant.

\section{RESULTS}

Detection and characterization of a new bipartite begomovirus associated with golden mosaic disease of B. erecta in the Dominican Republic. In PCR tests performed with degenerate DNA-A and DNA-B primer pairs, the expectedsize approximately $1.1-\mathrm{kb}$ and approximately $1.2-\mathrm{kb}$ DNA fragments were amplified from extracts prepared from absorption 
strips with sap of leaf samples from $B$. erecta plants with golden mosaic symptoms collected from four locations in the Azua Valley in 2012 (B1 sample) and 2013 (B2, B3-1, and B3-2 samples). A BLASTn search performed with the sequences of these fragments revealed highest identities of 81 and $75 \%$ with DNA-A and DNA-B sequences, respectively, of previously characterized NW bipartite begomoviruses (data not shown). These results indicated that the $B$. erecta plants with golden mosaic symptoms were infected with an uncharacterized NW bipartite begomovirus.

Full-length clones of the DNA-A and DNA-B components of the bipartite begomovirus isolate infecting each of the four $B$. erecta leaf samples (B1, B2, B3-1 and B3-2) were obtained by digestion of RCA products with $N d e I$ or EcoRI and cloning the resulting approximately $2.6-\mathrm{kb}$ fragments (monomers). Sequence analyses revealed that the DNA-A components of all four isolates are 2,600 $\mathrm{nt}$, whereas the DNA-B components are 2,575 nt. The genome size (approximately 2,600 nt) and organization of the DNA-A components (five ORFs: AV1, AC1, AC2, AC3, and AC4 encoding the capsid protein, Rep, transcription activator protein, replication enhancer, and AC4 proteins, respectively) are typical of NW bipartite begomoviruses. The size and genome organization of the DNA-B components are typical of those of bipartite begomoviruses (two ORFs: BV1 and BC1 encoding the nuclear shuttle protein [NSP] and MP, respectively). The complete nucleotide sequences of the DNA-A and DNA-B components of the begomovirus isolates from the four B. erecta leaf samples were 98 to $99 \%$ and 96 to $97 \%$ identical, respectively (Table 1 ). Consistent with these results, the $\mathrm{AV} 1, \mathrm{AC} 1, \mathrm{AC} 2, \mathrm{AC} 3, \mathrm{BV} 1$, and $\mathrm{BC} 1 \mathrm{ORF}$ of these components all had very high identities ( $\geq 97$ to $98 \%$ nt and $\geq 95$ to $98 \%$ amino acid [aa]), whereas identities for the AC4 ORF were slightly lower (98\% nt and $\geq 90$ to $93 \%$ aa). Together, these results indicated that the DNA-A and DNA-B components cloned from the four samples represent isolates of a bipartite begomovirus species.

Pairwise comparisons performed with the DNA-A and DNA-B sequences of the $\mathrm{B} 1$ isolate and those of other begomovirus species revealed the highest nucleotide identities for both the complete sequences and individual ORFs, with NW bipartite begomoviruses from Latin America, including many weed-infecting viruses from the Caribbean Basin (Table 1; Supplementary Fig. S1). For the DNA-A component, the highest nucleotide identities were $77 \%$ with Merremia mosaic virus (MerMV) from Puerto Rico and $76 \%$ with JMV from the Dominican Republic and a weed-infecting isolate of Tobacco yellow crinkle virus (TbYCV) from Jamaica, whereas the identity with the DNA-A component of BoYSV from Mexico was $74 \%$. These identities are well below the $91 \%$ threshold for describing a new begomovirus species (Brown et al. 2015). Thus, the four isolates from $B$. erecta plants with golden mosaic symptoms in the Dominican Republic represent a new species of NW bipartite begomovirus for which the name BoGMV is proposed. The designation of the four BoGMV isolates [in brackets] and GenBank accession numbers for DNA-A and DNA-B components (in parentheses) are as follows: [DO-Azua-B1-2012] (KY971533 and KY971534), [DO-Azua-B2-2013] (KY971535 and KY971536), [DO-Azua-B3-1-2013] (KY971537 and KY971538), and [DO-Azua-B3-2-2013] (KY971539 and KY971540).

The DNA-A and DNA-B components of each BoGMV isolate share a CR of 159 to $165 \mathrm{nt}$, with 91 to $93 \%$ identity (data not shown). The $\mathrm{CR}$ of all four isolates has the characteristic geminivirus stem-loop structure with the conserved nonanucleotide sequence TAATATT $\downarrow$ AC, Rep high-affinity binding sites (iterons), and the Rep TATA box and G-box (Gutierrez 1999; HanleyBowdoin et al. 1999). The CR of both components of all four isolates has the same iteron: GGAGG. The DNA-A CRs have a CCCCC inverted repeat, whereas the DNA-B CRs have a CCTCC inverted repeat. The iteron-related domain (IRD) in the $\mathrm{N}$ terminus of the Rep protein, which interacts with the iterons in the CR, is MPRKGAFSIN for all four isolates. Interestingly, this IRD is predicted to recognize the GGKGG iteron sequence $(\mathrm{K}=\mathrm{G}$ or $\mathrm{T})$ (Argüello-Astorga and Ruiz-Medrano 2001), which does not include the GGAGG iteron of BoGMV.

Phylogenetic analyses. In the phylogenetic tree generated with complete DNA-A sequences, the four BoGMV isolates were

TABLE 1. Nucleotide (nt) identities for total (Tot) and common region (CR) sequences and nucleotide and amino acid (aa) identities and similarities (in parenthesis) of individual open reading frames (ORFs) for the DNA-A and DNA-B components of the B1 isolate of Boerhavia golden mosaic virus (BoGMV) with those of three other BoGMV isolates from the Dominican Republic (DO) and the most closely related begomoviruses ${ }^{\mathrm{a}}$

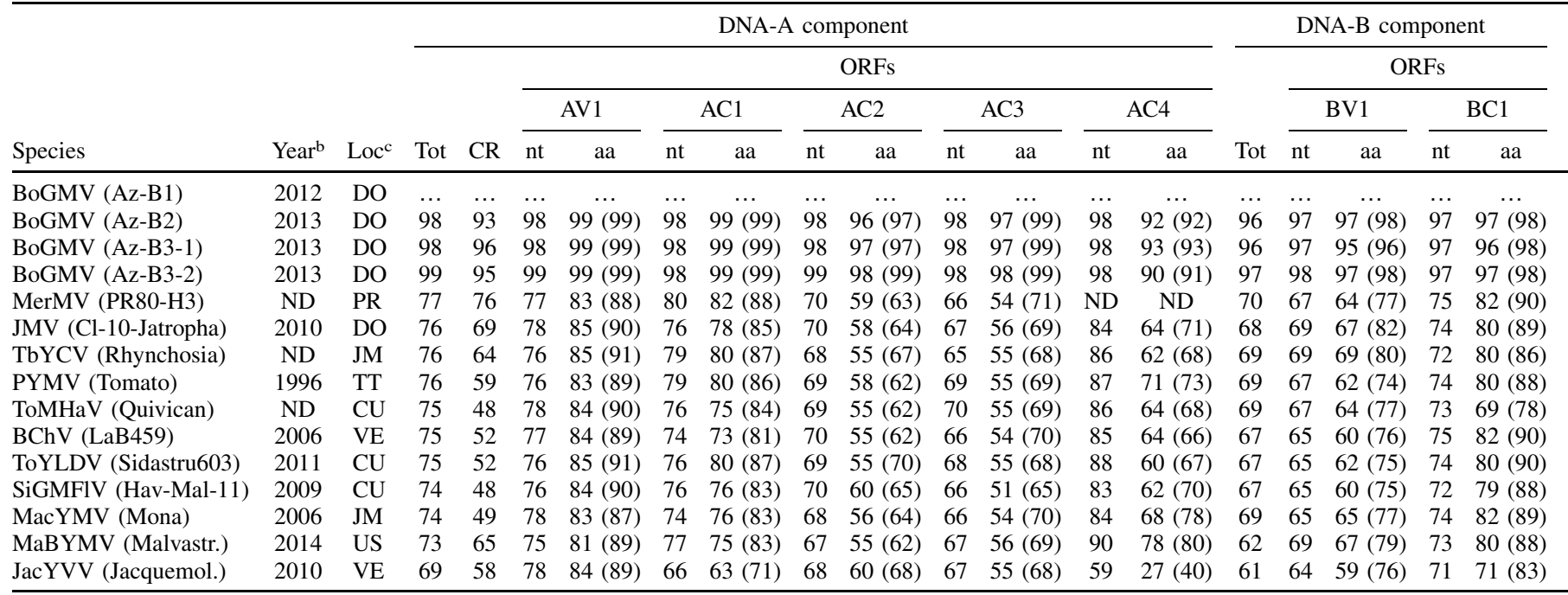

a Based on a BLASTn analysis, the most closely related begomoviruses were various New World bipartite begomoviruses. The begomoviruses used for comparison and their corresponding GenBank accession numbers are as follows: Merremia mosaic virus (MerMV) (DQ644557 and DQ644560), Jatropha mosaic virus (JMV) (KJ174331 and KJ174335), Tobacco yellow crinkle virus (TbYCV) (KP641345 and KP641346), Potato yellow mosaic virus (PYMV) (AF039031 and AF039032), Tomato mosaic Havana virus (ToMHaV) (Y14874 and Y14875), Bean chlorosis virus (BChV) (JN848770 and JN848771), Tomato yellow leaf distortion virus (ToYLDV) (KU232891 and KU232892), Sida golden mosaic Florida virus (SiGMFIV) (HM003779 and HM003778), Macroptilium yellow mosaic virus (MacYMV) (EF582840 and EF582841), Malvastrum bright yellow mosaic virus (MaBYMV) (KU058853 and KU058860), and Jacquemontia yellow vein virus (JacYVV) (KY617094 and KY617095). ND = not determined.

b Year collected.

${ }^{\mathrm{c}}$ Geographic location: $\mathrm{CU}=$ Cuba, $\mathrm{BR}=$ Brazil, $\mathrm{JM}=$ Jamaica, $\mathrm{PR}=$ Puerto Rico, $\mathrm{TT}=$ Trinidad and Tobago, US $=$ United States and VE $=$ Venezuela. 
placed together in a strongly supported cluster (PP of 1.0). This BoGMV lineage is distinct from the four previously identified lineages of NW bipartite begomoviruses (Fig. 1). The BoGMV cluster was placed in a larger, strongly supported clade (PP of 0.9) with the two isolates of MerMV from Puerto Rico. The isolate of BoYSV from Mexico was placed in the SLCuV lineage with other Mexican begomoviruses, consistent with it representing a species distinct from BoGMV. In the phylogenetic tree generated with complete DNA-B sequences, the BoGMV isolates were also placed together in a strongly supported cluster (PP of 1.0). This cluster was also placed in a larger strongly supported clade (PP of 0.8 ) with the MerMV isolates from Puerto Rico (Supplementary Fig. S2). As with the DNA-A phylogenetic tree, the BoGMV DNA-B lineage was distinct from the four known NW begomovirus lineages. These results are fully consistent with BoGMV representing a new species and a new phylogenetic lineage of NW bipartite begomoviruses.

Recombination analysis. Phylogenetic network analysis provides visual evidence of recombination. The topology of the network generated with the BoGMV DNA-A sequence and those of the most closely related begomoviruses was non-tree-like, and the star-shaped topology is suggestive of an evolutionary history involving recombination (Supplementary Fig. S3). Indeed, the PHI test indicated a highly significant probability of recombination $(P<$ $0.001)$. Consistent with this result, the RDP analysis identified a strongly supported recombination event in the DNA-A component of the BoGMV B1 isolate, which involved part of the $5^{\prime}$ end of the AC1 (Rep) ORF, the entire overlapping AC4 ORF, and part of the left side of the CR (breakpoints mapped to nucleotide positions 2,043 and 2,500) (Supplementary Fig. S4). The $P$ values were $2.5 \times$ $10^{-07}, 8.0 \times 10^{-18}, 1.3 \times 10^{-19}, 4.3 \times 10^{-07}, 7.7 \times 10^{-13}, 1.1 \times 10^{-17}$, $1.5 \times 10^{-12}$, and $3.3 \times 10^{-35}$ for the RDP, Geneconv, BootScan, MaxChi, Chimaera, SiScan, 3Seq, and LARD methods, respectively. An isolate of Malvastrum bright yellow mosaic virus (MaBYMV), associated with golden mosaic symptoms in the weed

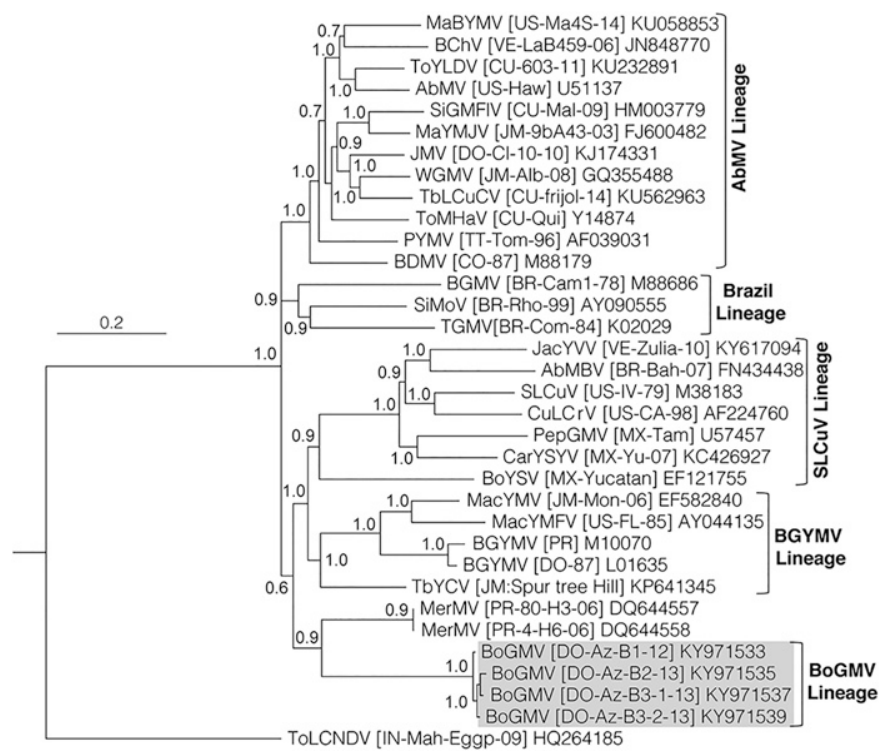

Fig. 1. Bayesian phylogenetic consensus tree generated from an alignment of the complete nucleotide sequences of the DNA-A component of four isolates of Boerhavia golden mosaic virus (BoGMV) from the Dominican Republic (shown in gray) and the most closely related begomoviruses (identified by a BLASTn search); selected begomoviruses representing the Abutilon mosaic virus (AbMV), Bean golden yellow mosaic virus (BGYMV), Brazil and Squash leaf curl virus (SLCuV) lineages of New World begomoviruses; and the DNA-A component of Boerhavia yellow spot virus (BoYSV) from Mexico. The DNA-A component of the Old World bipartite begomovirus Tomato leaf curl New Delhi virus (ToLCNDV) was used as an out-group. Branch strengths were evaluated by Bayesian posterior probabilities. The scale bar represents the numbers of nucleotide substitutions per site. GenBank accession numbers are indicated.
Malvastrum spp. in South Texas, United States (Alabi et al. 2016), was identified as a possible minor parent involved in this recombinant event.

Infectivity, symptomatology, and host range of BoGMV. $B$. erecta seedlings agroinoculated with the cloned multimeric DNA-A and DNA-B components of the B1 isolate of BoGMV were stunted and developed golden mosaic symptoms in newly emerged leaves by 14 dpi (Fig. 2A), whereas equivalent plants agroinoculated with the EV control did not develop symptoms (Fig. 2B). The BoGMV DNA-A and DNA-B components were detected in newly emerged leaves of $B$. erecta plants with golden mosaic symptoms in PCR tests with BoGMV component-specific primer pairs, and not from leaves of symptomless EV control plants (Table 2). These results established that the cloned DNA-A and DNA-B components of BoGMV (B1 isolate) were infectious and induced golden mosaic symptoms in $B$. erecta, thereby fulfilling Koch's postulates for this disease. Furthermore, when sap prepared from leaves of $B$. erecta plants with golden mosaic symptom was mechanically inoculated onto the first true leaves of $B$. erecta
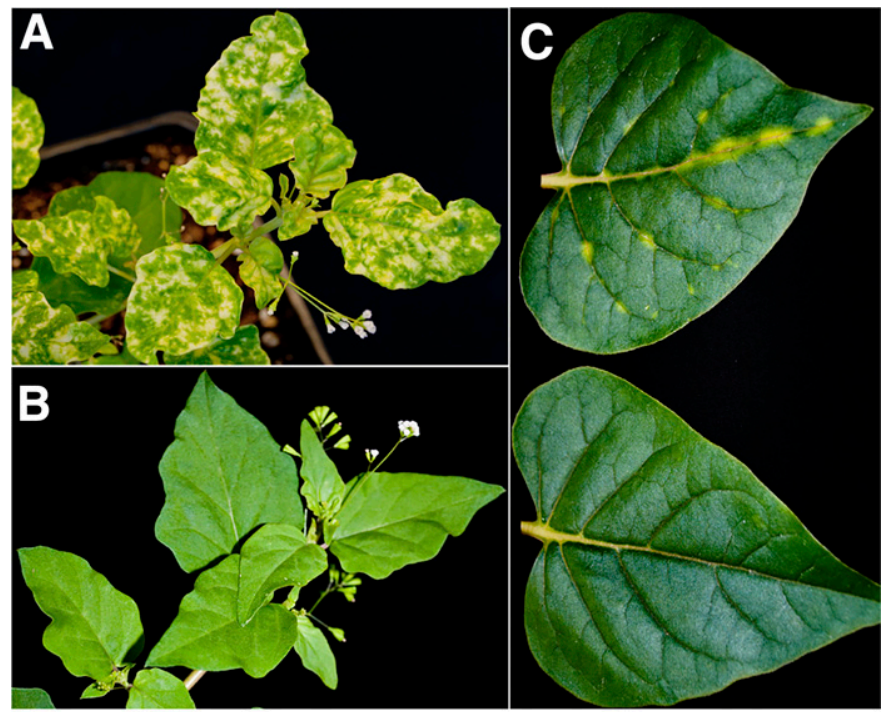

D

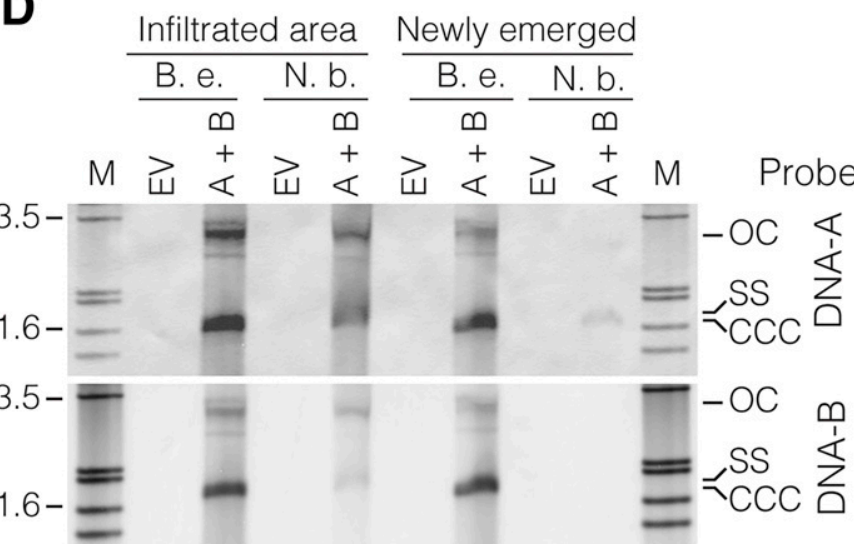

Fig. 2. Disease symptoms induced by the cloned DNA-A and DNA-B components of the B1 isolate of Boerhavia golden mosaic virus (BoGMV). A, Golden mosaic symptoms induced in a Boerhavia erecta plant 21 days postagroinoculation (dpi). B, B. erecta plant agroinoculated with the empty vector control and showing no symptoms $21 \mathrm{dpi}$. C, Yellow vein spotting symptoms induced in a leaf of a Mirabilis jalapa plant $18 \mathrm{dpi}$ (top), compared with a leaf of a negative control plant agroinoculated with the empty vector (bottom). D, Southern blot hybridization analyses showing replicative forms of BoGMV DNA-A and DNA-B components in B. erecta and Nicotiana benthamiana leaf patches 5 days after agroinfiltration (daa), and in newly emerged (noninoculated) leaves 21 daa. Blots in the upper and lower panels were hybridized with BoGMV DNA-A and DNA-B probes, respectively. Lane $\mathrm{M}=$ size marker (kb) and lane $\mathrm{EV}=$ empty vector. Open circular (OC), single-stranded (SS), and covalently closed circular (CCC) DNA forms are indicated. 
seedlings, golden mosaic symptoms, indistinguishable from those in agroinoculated plants, developed in newly emerged leaves of all inoculated plants by $12 \mathrm{dpi}$ (Table 2). This result established that BoGMV is sap transmissible to $B$. erecta plants.

Unexpectedly, none of the $N$. benthamiana plants agroinoculated with the infectious cloned BoGMV DNA-A and DNA-B components developed symptoms by 24 dpi (Table 2). When newly emerged leaves of these plants were tested by PCR with BoGMV component-specific primer pairs, the DNA-A but not the DNA-B component was detected. Furthermore, when $N$. benthamiana plants were mechanically inoculated with sap prepared from (i) leaves of $N$. benthamiana plants infected with BoGMV DNA-A only or (ii) leaves of $B$. erecta plants with golden mosaic symptoms (infected with BoGMV DNA-A and DNA-B), no symptoms developed, nor was either DNA component detected in newly emerged leaves of these plants by PCR with the BoGMV component-specific primer pairs.

The host range of BoGMV was next investigated by agroinoculation and mechanical inoculation of the plant species shown in Table 2. With agroinoculation, the only other species infected by BoGMV were $M$. jalapa and $M$. expansa, which are also members of the family Nyctaginaceae. Agroinoculated $M$. jalapa plants developed yellow spots in veins of newly emerged leaves by $14 \mathrm{dpi}$ (Fig. 2C), whereas no symptoms developed in agroinoculated M. expansa plants. In PCR tests of newly emerged leaves, BoGMV DNA-A and DNA-B components were detected in the symptomatic M. jalapa plants, whereas both components were detected in $50 \%$ (14 of 28) of the symptomless M. expansa plants (Table 2). None of the $M$. jalapa and $M$. expansa plants mechanically inoculated with sap prepared from BoGMV-infected $B$. erecta leaves developed symptoms or were infected by BoGMV based on PCR tests of newly emerged leaves. Thus, only B. erecta plants were infected with BoGMV following mechanical inoculation (Table 2). These results indicated that BoGMV has an extremely restricted host range, limited to species in the family Nyctaginaceae and not including the permissive host $N$. benthamiana.

Leaf disk replication and cell-to-cell movement assays. We next investigated the replication properties of BoGMV in leaves of $B$. erecta and $N$. benthamiana plants. Replicative forms of the BoGMV DNA-A and DNA-B components were detected in agroinfiltrated leaf patches of $B$. erecta and $N$. benthamiana by Southern blot hybridization analyses with DNA-A- and
DNA-B-component-specific probes (Fig. 2D). Thus, BoGMV replicated in $B$. erecta and $N$. benthamiana leaves, although higher levels of replication were consistently detected in $B$. erecta leaves (in three independent experiments). These results are in agreement with results of plant infectivity experiments in which symptomless DNAA-only infections were detected in newly emerged leaves of $N$. benthamiana plants agroinoculated with BoGMV DNA-A and DNA-B. These results also indicated that the DNA-A-only infections were not due to a deficiency in DNA-B replication in this host. Instead, these infections were due to the agroinoculation method, which facilitates the systemic movement of DNA-A alone, as previously reported for other bipartite begomoviruses in this host.

We next tested the hypothesis that the inability of BoGMV to systemically infect and cause symptoms in $N$. benthamiana was due to a deficiency in cell-to-cell movement by determining the capacity of BoGMV to move out of agroinfiltrated leaf patches (Fig. 3A). As a positive control, we used JMV, which systemically infects and causes severe symptoms (stunting, distorted growth, and crumpling, epinasty, and mottling of leaves) in $N$. benthamiana plants, and is also sap transmissible to this host (Melgarejo et al. 2015). In this experiment, restriction enzyme digestion analysis of begomovirus DNA components, amplified by RCA, was used to detect BoGMV and JMV DNA-A and DNA-B components (Supplementary Fig. S5). For JMV, the expected-size fragments of DNA-A (approximately $2.6 \mathrm{~kb}$ ) and DNA-B (approximately $1.1 \mathrm{~kb}$ and approximately $1.5 \mathrm{~kb}$ ) were detected inside and outside of infiltrated patches at 4,7 , and 10 daa, indicating replication and cell-to-cell movement in $N$. benthamiana leaves (Fig. 3B). In patches agroinfiltrated with JMV DNA-A only, the approximately 2.6-kb DNA-A fragment was detected inside but not outside of these patches (Fig. 3B). This is consistent with the capacity of JMV DNA-A to replicate in $N$. benthamiana leaves, and the requirement for the DNA-B component for cell-to-cell movement. In the case of BoGMV, the expected-size fragments of DNA-A (approximately $2.6 \mathrm{~kb}$ ) and DNA-B (approximately $0.6 \mathrm{~kb}$ and approximately $2.0 \mathrm{~kb}$ ) were detected inside but not outside of the agroinfiltrated patches at 4, 7, and 10 daa (Fig. 3B). This indicated an inability of BoGMV to move cell to cell in leaves of $N$. benthamiana plants. In patches agroinfiltrated with BoGMV DNA-A only, the expected-size approximately 2.6-kb DNA-A fragment was detected inside but not outside of these patches. This is consistent with the capacity of the BoGMV DNA-A component

TABLE 2. Host range and symptomatology of the B1 isolate of Boerhavia golden mosaic virus (BoGMV) from the Dominican Republic ${ }^{2}$

\begin{tabular}{|c|c|c|c|c|c|c|c|}
\hline \multirow[b]{3}{*}{ Species } & & & \multicolumn{4}{|c|}{ Infectivity $^{\mathrm{b}}$} & \multirow[b]{3}{*}{ Symptom type } \\
\hline & \multicolumn{2}{|c|}{ Symptoms ${ }^{\mathrm{c}}$} & \multicolumn{2}{|c|}{ Agro } & \multicolumn{2}{|c|}{ Sap } & \\
\hline & Agro & Sap & DNA-A & DNA-B & DNA-A & DNA-B & \\
\hline Boerhavia erecta & $22 / 22$ & $22 / 22$ & $22 / 22$ & $22 / 22$ & $14 / 14$ & $14 / 14$ & Golden mosaic, stunting \\
\hline Mirabilis jalapa & $11 / 21$ & $0 / 25$ & $11 / 21$ & $11 / 21$ & $0 / 14$ & $0 / 14$ & Yellow spotting of veins \\
\hline M. expansa & $0 / 28$ & $0 / 19$ & $14 / 28$ & $14 / 28$ & $0 / 15$ & $0 / 15$ & Symptomless \\
\hline Nicotiana benthamiana & $0 / 42$ & $0 / 39$ & $42 / 42$ & $0 / 42$ & $0 / 21$ & $0 / 21$ & Symptomless \\
\hline N. glutinosa & $0 / 32$ & $0 / 17$ & $0 / 32$ & $0 / 32$ & $0 / 14$ & $0 / 14$ & No infection \\
\hline N. tabacum 'Samsun' & $0 / 32$ & $0 / 17$ & $0 / 32$ & $0 / 32$ & $0 / 14$ & $0 / 14$ & No infection \\
\hline Datura stramonium & $0 / 32$ & $0 / 16$ & $0 / 32$ & $0 / 32$ & $0 / 12$ & $0 / 12$ & No infection \\
\hline Solanum lycopersicon 'Glamour' & $0 / 33$ & $0 / 33$ & $0 / 33$ & $0 / 33$ & $0 / 12$ & $0 / 12$ & No infection \\
\hline Phaseolus vulgaris 'Topcrop' & $0 / 26$ & $0 / 14$ & $0 / 26$ & $0 / 26$ & $0 / 14$ & $0 / 14$ & No infection \\
\hline Cucurbita pepo 'Small sugar' & $0 / 33$ & $0 / 11$ & $0 / 33$ & $0 / 33$ & $0 / 11$ & $0 / 11$ & No infection \\
\hline Chenopodium quinoa & $0 / 31$ & $0 / 17$ & $0 / 31$ & $0 / 31$ & $0 / 17$ & $0 / 17$ & No infection \\
\hline C. amaranticolor & $0 / 32$ & $0 / 17$ & $0 / 32$ & $0 / 32$ & $0 / 15$ & $0 / 15$ & No infection \\
\hline Capsicum annuиm 'Cayenne Long Red' & $0 / 47$ & $0 / 25$ & $0 / 47$ & $0 / 47$ & $0 / 14$ & $0 / 14$ & No infection \\
\hline Ocimum basilicum & $0 / 15$ & $0 / 12$ & $0 / 15$ & $0 / 15$ & $0 / 12$ & $0 / 12$ & No infection \\
\hline
\end{tabular}

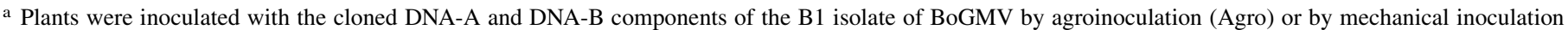
with sap prepared from symptomatic $B$. erecta leaves collected from plants infected following agroinoculation (Sap).

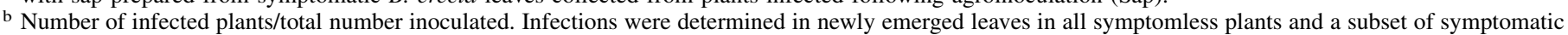
plants by PCR with BoGMV-specific DNA-A and DNA-B primer pairs 20 to 24 days postinoculation (dpi). Results represent data from three independent experiments.

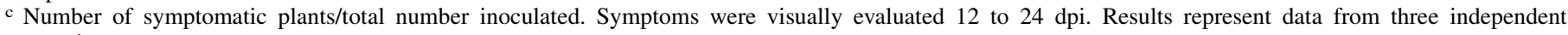
experiments. 
to replicate in $N$. benthamiana. In patches agroinfiltrated with the JMV or BoGMV DNA-B components, no replication or cell-tocell movement was detected. Together, these results revealed that BoGMV is deficient in cell-to-cell movement in $N$. benthamiana leaves, whereas JMV readily moved cell to cell, consistent with the capacity of this virus to systemically infect and induce severe symptoms in this host.
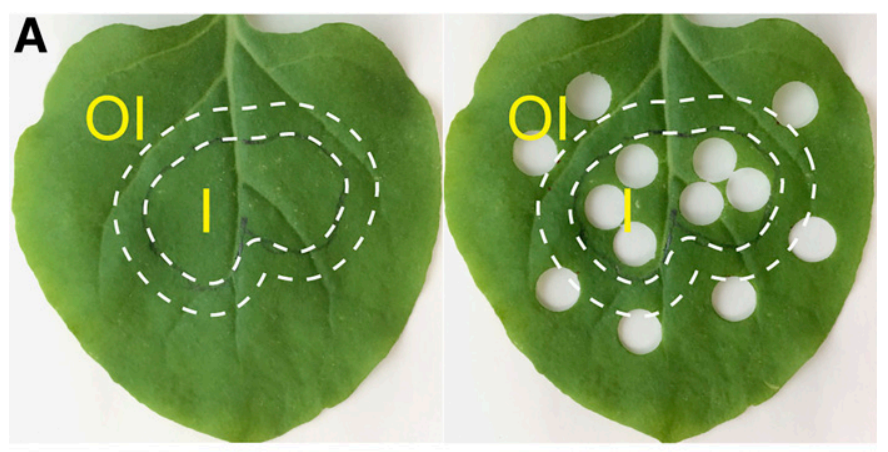

B

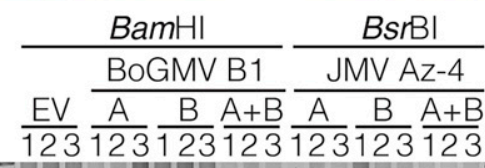
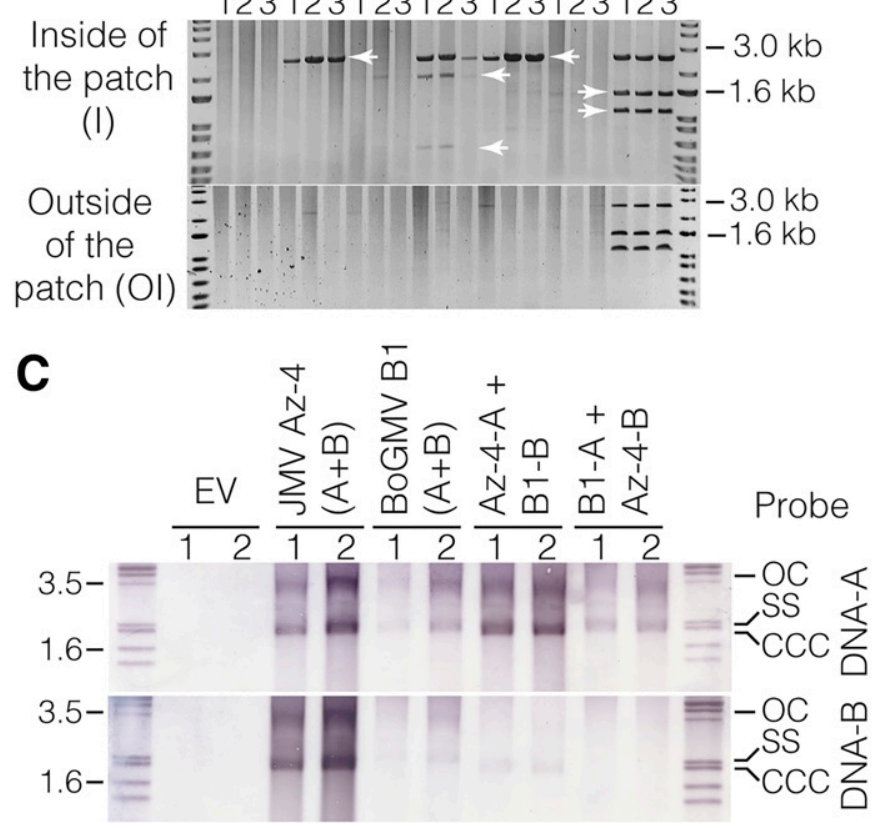

Fig. 3. Cell-to-cell movement assay of Boerhavia golden mosaic virus (BoGMV) isolate B1 and Jatropha mosaic virus (JMV) strain Az-4, and replication assay of pseudorecombinants (PRs) generated with the infectious cloned DNA components of BoGMV and JMV in leaves of Nicotiana benthamiana plants. A, N. benthamiana leaves showing the agroinfiltrated patch (I) and the area outside of the patch (OI, approximately $5 \mathrm{~mm}$ away from the border of the infiltrated patch), and the pattern and size of the leaf disks collected for detection of viral DNA components by rolling circle amplification (RCA) and restriction enzyme digestion. Leaf disk samples were taken at 4, 7, and 10 days after agroinfiltration (daa) with the DNA-A and DNA-B components or the DNA-A or DNA-B component only. B, Restriction fragments of BoGMV B1 and JMV Az-4 DNA components following RCA, restriction enzyme digestion, and agarose gel electrophoresis. Lanes 1, 2, and 3 $=4,7$, and 10 daa, respectively. White arrows indicate the expected size fragments for the DNA-A and DNA-B components. C, Southern blot hybridization analyses showing replicative forms and levels of the DNA-A and DNA-B components of BoGMV B1 and JMV Az-4 and PRs formed with the infectious cloned DNA-A and DNA-B components of these viruses in leaf patches of $N$. benthamiana plants 5 daa. Blots in the upper and lower panels were hybridized with DNA-A and DNA-B probes, respectively. Far left and right lanes = size marker $(\mathrm{kb})$ and lane $\mathrm{EV}=$ empty vector. Open circular (OC), single-stranded (SS), and covalently closed circular (CCC) DNA forms are indicated. Total DNA was extracted from each of two plants (lanes 1 and 2) per treatment.
To map the viral factor or factors involved in cell-to-cell movement properties of BoGMV and JMV in $N$. benthamiana, we next investigated whether viable PRs could be generated between the infectious cloned DNA components of these viruses. When agroinoculated into $N$. benthamiana plants, the JMV-DNA-A/ BoGMV-DNA-B and BoGMV-DNA-A/JMV-DNA-B PRs did not induce symptoms. As expected, plants agroinoculated with JMV DNA-A and DNA-B developed severe symptoms, whereas those agroinoculated with BoGMV DNA-A and DNA-B were symptomless. PCR tests of newly emerged leaves revealed DNA-A-only infections in all plants agroinoculated with both PRs but DNA-B was not detected in any of these plants. Thus, these plants had symptomless DNA-A-only infections (Supplementary Table S2), similar to those previously described for plants agroinoculated with BoGMV DNA-A and DNA-B. Equivalent PCR tests revealed DNA-A and DNA-B components in symptomatic leaves of plants agroinoculated with JMV DNA-A and DNA-B, whereas the expected symptomless DNA-A-only infections were detected in plants agroinoculated with BoGMV DNA-A and DNA-B. Leaf disk replication assays with the PRs further revealed that the BoGMV DNA-A component did not mediate the replication of the JMV DNA-B component, nor did the JMV DNA-A component mediate the replication of the BoGMV DNA-B component (Fig. $3 \mathrm{C}$ ). Thus, although JMV is one of the begomoviruses most closely related to BoGMV (Table 1), the failure to generate viable PRs between these viruses likely reflects sequence divergence in the $\mathrm{CR}$, including different iterons and the Rep IRDs. These results are also consistent with BoGMV and JMV representing distinct species in different phylogenetic lineages. Thus, we could not use PR experiments to map the viral determinants of cell-to-cell movement of these two begomoviruses.

The MP, encoded by the BC1 ORF of the DNA-B component, plays an essential role in begomovirus cell-to-cell movement. Therefore, it was hypothesized that amino acid differences in the MPs of BoGMV and JMV underlie the different cell-to-cell movement capacities of these viruses in $N$. benthamiana. The MP amino acid sequences of JMV and BoGMV are $79 \%$ identical, and analysis of an alignment of these sequences revealed that 62 of 293 aa are different $(21 \%$, data not shown). To narrow down possible differences involved in cell-to-cell movement, an alignment of MP amino acid sequences of $15 \mathrm{NW}$ begomoviruses, selected on the basis of their differential virulence in $N$. benthamiana, was generated. The virulence properties of these viruses are as follows: SL-A, symptomless DNA-A-only infection (e.g., BoGMV); SLA/B, symptomless DNA-A and DNA-B infection (e.g., Cucurbit leaf crumple virus [CuLCrV], Bean golden mosaic virus [BGMV], and BGYMV) (Garrido-Ramirez et al. 2000a; Hagen et al. 2008; Petty et al. 2000); and SI-A/B, symptomatic DNA-A and DNA-B infection. Eight regions of the MP alignment were examined based on previous studies showing a role in cell-to-cell movement and pathogenicity (Ingham et al. 1995; Noueiry et al. 1994). Inspection of these aligned regions revealed a single amino acid difference at position 260, where the SL-A virus (BoGMV) has a Thr residue, the SL-A/B viruses (CuLCrV, BGMV, and BGYMV) have Thr or Ser residues, and the 11 SI-A/B viruses have Asn or His residues (Supplementary Fig. S6).

To test the hypothesis that amino acid differences at position 260 were responsible for the inability of BoGMV to move cell to cell in $N$. benthamiana leaves, a mutation in the BoGMV BC1 sequence was introduced that changed Thr260 to Asn260, and the corresponding mutation was introduced into the JMV BC1 sequence that changed Asn260 to Thr260. As expected, control $N$. benthamiana plants agroinoculated with BoGMV DNA-A and DNA-B were symptomless, whereas those agroinoculated with JMV DNA-A and DNA-B were stunted and developed crumpling, epinasty, and mottling of leaves. $N$. benthamiana plants agroinoculated with BoGMV DNA-A and the DNA-B Thr260Asn mutant were symptomless, whereas plants agroinoculated with 
JMV DNA-A and the DNA-B Asn260Thr mutant were stunted and developed leaf crumpling, epinasty, and mottling, indistinguishable from wild-type JMV infection (Supplementary Table S3). PCR tests revealed symptomless DNA-A-only infections in plants agroinoculated with BoGMV DNA-A and the DNA-B Thr260Asn mutant, whereas DNA-A and DNA-B components were detected in symptomatic leaves of plants agroinoculated with JMV DNA-A and the DNA-B Asn260Thr mutant. Thus, this single amino acid difference in the BoGMV and JMV MPs was not the determinant of cell-to-cell movement capacity of these viruses in $N$. benthamiana.

\section{DISCUSSION}

In tropical and subtropical regions of the world, noncultivated plants, especially weeds, are commonly infected by begomoviruses and often show striking golden yellow mosaic symptoms. To date, most begomoviruses characterized from noncultivated plants have been genetically distinct from those infecting crops, and are only very rarely detected in crops (and vice versa). Because begomovirus-infected weeds of multiple species are often observed in and around agricultural fields, such plants are widely believed to harbor crop-infecting viruses. Thus, the relationship between weedand crop-infecting begomoviruses remains unclear. There are two major hypotheses: (i) weeds serve as reservoirs for crop-infecting begomoviruses and (ii) weed-infecting begomoviruses serve as progenitors for local evolution of crop-adapted viruses (Gilbertson et al. 2015; Inoue-Nagata et al. 2016; Jones 2009). Therefore, molecular characterization of weed-infecting begomoviruses provides important practical information in terms of management of crop-infecting begomoviruses, as well as insight into viral evolution.

In the present study, we describe a new NW bipartite begomovirus associated with golden mosaic symptoms in $B$. erecta plants in the Azua Valley of the southeastern Dominican Republic. Because this weed is commonly found in and around agricultural fields in the Dominican Republic (Santos et al. 2008), it is important to know the viruses harbored in this plant and their potential to infect crops. The sequence of the DNA-A component of the begomovirus from $B$. erecta had identities of $<80 \%$ with those of previously characterized begomoviruses, including those infecting crops and weeds in the Caribbean Basin and BoYSV from Mexico. The current International Committee on Taxonomy of Viruses criteria for the demarcation of begomovirus species is $<91 \% \mathrm{nt}$ identity with the DNA-A components of recognized species. Therefore, the begomovirus infecting B. erecta in the Dominican Republic is a new species, and the name BoGMV is proposed based on the striking disease symptoms observed in the field. Furthermore, the development of golden mosaic symptoms in B. erecta plants agroinoculated with the cloned multimeric DNA-A and DNA-B components of BoGMV fulfilled Koch's postulates for this disease and confirmed that these symptoms are caused by this bipartite begomovirus.

The genome organization of BoGMV is typical of NW bipartite begomoviruses but this virus possesses several notable properties. Phylogenetic analyses established that the BoGMV isolates from the Dominican Republic constitute a new and distinct lineage of NW bipartite begomoviruses. Most likely, this lineage originated following local evolution and adaptation of a progenitor begomovirus to infect and cause symptoms in $B$. erecta. This hypothesis was supported by the finding that the closest relatives of BoGMV are weed-infecting bipartite begomoviruses from the Caribbean Basin (e.g., MerMV from Puerto Rico, JMV from the Dominican Republic, and TbYCV from Jamaica). However, the relatively low sequence identities $(<80 \%)$ of these begomoviruses with BoGMV indicate a long period of diversification and host adaptation. Further evidence for this came from the inability to make viable BoGMV/JMV PRs, which reflected divergence in the iterons and Rep IRD sequences (Argüello-Astorga and Ruiz-Medrano 2001; Fontes et al. 1994). Furthermore, BoGMV has a distinct iteron not previously predicted to be recognized by its IRD, and this may be a feature of the BoGMV lineage. Together, these results suggest that BoGMV diverged from (i) a common progenitor virus over a long period of time or (ii) from one of multiple divergent progenitors that independently evolved to infect different weed species in the Caribbean Basin. Independent evolution from genetically distinct progenitors explains the high degree of divergence between BoGMV from the Dominican Republic and BoYSV from Mexico.

Most begomoviruses have relatively narrow host ranges, which typically include species in only one to three families (e.g., Cucurbitaceae, Fabaceae, and Solanaceae). A few have broader host ranges (e.g., ToLCNDV and Tomato severe rugose virus, which infect plant species in five and six families, respectively) (Barbosa et al. 2011; Moury et al. 2017; Zaidi et al. 2017). Our results revealed that the host range of BoGMV is limited to $B$. erecta and two other species in the family Nyctaginaceae. This indicates a high degree of host adaptation that likely occurred over a long period of time. Furthermore, the high degree of sequence identity among the four BoGMV isolates collected from different locations and times (years) is consistent with a high degree of host adaptation and the placement of these isolates in a distinct phylogenetic lineage. A similar degree of host adaptation and specificity has been reported for the OW legume-infecting Dolichos yellow mosaic virus, which infected only Lablab purpureus out of 36 species tested. Furthermore, isolates of this virus were also placed in a distinct phylogenetic lineage (Maruthi et al. 2006; Qazi et al. 2007).

The adaptation of BoGMV to B. erecta likely involved the multiple evolutionary forces that shape genetic diversity in virus populations (i.e., mutation, PR, and recombination) (Holmes 2009). The high degree of divergence across the entire BoGMV genome, even with the most closely related bipartite NW begomoviruses, indicates extensive evolution via mutation, a major means of begomovirus diversification (Duffy and Holmes 2009; Duffy et al. 2008). In addition, a recombination event was identified in the BoGMV DNA-A component, and included the entire AC4 ORF. A possible donor of this genomic region was identified by RDP as the weed-infecting begomovirus MaBYMV from South Texas. Following the evolution and host adaptation of BoGMV, subsequent plant-to-plant spread and maintenance in $B$. erecta would have been mediated by local whitefly vector populations (Bastidas et al. 2008; De Marchi et al. 2017). The introduction and establishment of the polyphagous MEAM1 species (biotype B) of Bemisia tabaci in the Dominican Republic could change the prevalence or even host range of BoGMV, depending on the preference of these whiteflies for $B$. erecta.

In terms of crop production in the Dominican Republic, the low degree of genetic diversity and high degree of host specificity (narrow host range) of BoGMV minimizes the likelihood that this virus will infect crop plants or serve as a progenitor for cropinfecting begomoviruses. There are few crops in the Nyctaginaceae family (Van Zant et al. 2018), and none of these are grown in the Dominican Republic. This is in contrast to JMV, which has a higher degree of genetic diversity and a wider host range, which includes the crop plants common bean and tobacco (Melgarejo et al. 2015). Therefore, BoGMV can be considered a specialist, whereas JMV is more of a generalist, with greater potential to cause disease in crops or evolve into a crop-infecting begomovirus (Elena 2017; Jones 2009). Thus, the specialist begomovirus BoGMV does not appear to pose a threat to agriculture or warrant implementation of management strategies such as roguing symptomatic $B$. erecta plants. In contrast, $B$. erecta is a reservoir host for the invasive Tomato chlorotic spot virus (TCSV), an economically important tomato-infecting tospovirus recently introduced in the Caribbean Basin (Gilbertson et al. 2015). In the Dominican Republic and Puerto Rico, TCSV induces stunting and chlorosis symptoms in $B$. erecta and such plants may be an inoculum source for this virus 
(Batuman et al. 2014; Estévez de Jensen et al. 2017; Gilbertson et al. 2015).

Another notable feature of BoGMV was the interaction with $N$. benthamiana. Unlike most begomoviruses, BoGMV did not induce a typical infection in this permissive host (i.e., replication, systemic spread of both components, and development of disease symptoms). The BoGMV DNA-A-only infection detected in N. benthamiana plants agroinoculated with the DNA-A and DNA-B components is a wellknown phenomenon associated with this inoculation method, and is characterized by no symptoms, low virus titers, and inability to be mechanically transmitted (Buragohain et al. 1994; Evans and Jeske 1993; Frischmuth et al. 1993; Galvao et al. 2003; Garrido-Ramirez et al. 2000a; Hou et al. 1998; Klinkenberg and Stanley 1990). However, the DNA-A-only infection did reveal the capacity for BoGMV to replicate in $N$. benthamiana, and this was confirmed with the leaf disk replication assays. These assays further showed that BoGMV DNA-A replicated the cognate DNA-B component in $N$. benthamiana leaves, which suggested that a deficiency in viral movement was responsible for the inability of BoGMV to infect $N$. benthamiana. Indeed, this was demonstrated by the failure to detect the BoGMV DNA components in leaf disks taken from outside of agroinfiltrated patches in $N$. benthamiana leaves. In contrast, the DNA-A and DNA-B components of JMV were consistently detected in leaf disks taken from outside of the agroinfiltrated patches, which revealed cell-tocell movement and is consistent with systemic infection and symptom development in this host (Melgarejo et al. 2015).

Because the failure of BoGMV to infect $N$. benthamiana was due to a deficiency in cell-to-cell movement, we next analyzed amino acid sequences of the MP for candidate amino acid residues possibly involved in this process. The amino acid alignment of MP sequences of begomoviruses with differential virulence in $N$. benthamiana revealed a Thr residue at position 260 for BoGMV, whereas begomoviruses that systemically infect and cause symptoms in $N$. benthamiana mostly have an Asn residue at this position. Furthermore, mutation of this residue in the MP of SLCuV abolished infectivity in $N$. benthamiana plants and the mutant MP had an altered subcellular localization and ability to relocalize the NSP protein in transient expression studies (Ingham et al. 1995; Sanderfoot and Lazarowitz 1995); thus, we hypothesized that the amino acid difference at this position was involved in adaptation of BoGMV to $B$. erecta and the inability to move cell to cell in $N$. benthamiana. However, this hypothesis was rejected because the BoGMV mutant expressing the Thr260Asn MP did not systemically infect and cause symptoms in $N$. benthamiana, whereas the JMV mutant expressing the Asn260Thr MP did not lose this capacity. Thus, the altered MPs retained their respective cell-to-cell movement properties. It is likely that the host adaptation of BoGMV to $B$. erecta is more complex and involves other amino acid changes in the MP or other viral proteins or non-coding regions (GarridoRamirez et al. 2000b; Ingham et al. 1995; Petty et al. 2000; Zhou et al. 2007).

In conclusion, we have characterized a new NW bipartite begomovirus, BoGMV, which induces golden mosaic symptoms in $B$. erecta plants in the Dominican Republic. We further established that BoGMV has a high degree of host adaptation, only infecting members of the family Nyctaginaceae, especially $B$. erecta. BoGMV isolates collected from different locations and times had a low level of genetic diversity and constitute a new lineage of NW begomoviruses. Together, this suggests that BoGMV has become well-adapted to $B$. erecta, most likely over a long period of time and involving extensive mutation and at least one recombination event. The high degree of host specificity and the inability to infect plant species in five other families, including several crop plants, indicates that BoGMV does not pose a threat to agricultural production in the Dominican Republic. Finally, the inability of BoGMV to infect the permissive laboratory host $N$. benthamiana was due to a deficiency in cell-to-cell movement but this deficiency was not due to an amino acid difference at position 260 in the MP.

\section{ACKNOWLEDGMENTS}

We thank A. Almanzar of Transagricola, S. A. (Av. Duarte 269 Navarrete, Santiago, Dominican Republic, Apartado 713) for assistance in collecting the $B$. erecta samples used in this study and V. Villagomez from the Programa de Tuberculos y Raices at the Universidad Nacional Agraria La Molina (UNALM), Lima, Peru for providing M. expansa seed.

\section{LITERATURE CITED}

Alabi, O. J., Villegas, C., Gregg, L., and Murray, K. D. 2016. Complete nucleotide sequences of a new bipartite begomovirus from Malvastrum sp. plants with bright yellow mosaic symptoms in South Texas. Arch. Virol. 161:1729-1733.

Ambrozevicius, L. P., Calegario, R. F., Fontes, E. P. B., Carvalho, M. G., and Zerbini, M. F. 2002. Genetic diversity of begomovirus infecting tomato and associated weeds in Southeastern Brazil. Fitopatol. Bras. 27:372-377.

Argüello-Astorga, G., and Ruiz-Medrano, R. 2001. An iteron-related domain is associated to Motif 1 in the replication proteins of geminiviruses: Identification of potential interacting amino acid-base pairs by a comparative approach. Arch. Virol. 146:1465-1485.

Barbosa, J. C., da Silva Barreto, S., Inoue-Nagata, A. K., and Rezende, J. A. M. 2011. Characterization and experimental host range of a Brazilian tomato isolate of Tomato severe rugose virus. J. Phytopathol. 159:644-646.

Barboza, N., Blanco-Meneses, M., Esker, P., Moriones, E., and Inoue-Nagata, A. 2018. Distribution and diversity of begomoviruses in tomato and sweet pepper plants in Costa Rica. Ann. Appl. Biol. 172:20-32.

Barreto, S., Hallwass, M., Aquino, O., and Inoue-Nagata, A. 2013. A study of weeds as potential inoculum sources for a tomato-infecting begomovirus in central Brazil. Phytopathology 103:436-444.

Bastidas, H., Pantoja, A., Lugo, M. L., and Stansly, P. 2008. Malezas hospederas de la mosca blanca en siembras de tomate en el sur de Puerto Rico. J. Agric. P.R. 92:231-234.

Batuman, O., Rojas, M. R., Almanzar, A., and Gilbertson, R. L. 2014. First report of Tomato chlorotic spot virus in processing tomatoes in the Dominican Republic. Plant Dis. 98:286.

Blawid, R., Fontenele, R. S., Lacorte, C., and Ribeiro, S. G. 2013. Molecular and biological characterization of corchorus mottle virus, a new begomovirus from Brazil. Arch. Virol. 158:2603-2609.

Brown, J. K., Zerbini, F. M., Navas-Castillo, J., Moriones, E., Ramos-Sobrinho, R., Silva, J. C., Fiallo-Olivé, E., Briddon, R. W., Hernández-Zepeda, C., and Idris, A. 2015. Revision of Begomovirus taxonomy based on pairwise sequence comparisons. Arch. Virol. 160:1593-1619.

Bruen, T. C., Philippe, H., and Bryant, D. 2006. A simple and robust statistical test for detecting the presence of recombination. Genetics 172:2665-2681.

Bryant, D., and Moulton, V. 2004. Neighbor-net: An agglomerative method for the construction of phylogenetic networks. Mol. Biol. Evol. 21:255-265.

Buragohain, A., Sung, Y., Coffin, R., and Coutts, R. H. 1994. The infectivity of dimeric potato yellow mosaic geminivirus clones in different hosts. J. Gen. Virol. 75:2857-2861.

Chen, S.-H., and Wu, M.-J. 2007. A taxonomical study of the genus Boerhavia (Nyctaginaceae) in Taiwan. Taiwania 52:332-372.

Darriba, D., Taboada, G. L., Doallo, R., and Posada, D. 2012. jModelTest 2: More models, new heuristics and parallel computing. Nat. Methods 9:772.

da Silva, S. J. C., Castillo-Urquiza, G. P., Hora-Júnior, B. T., Assunção, I. P., Lima, G. S. A., Pio-Ribeiro, G., Mizubuti, E. S. G., and Zerbini, F. M. 2011. High genetic variability and recombination in a begomovirus population infecting the ubiquitous weed Cleome affinis in northeastern Brazil. Arch. Virol. 156:2205-2213

Dellaporta, S. L., Wood, J., and Hicks, J. B. 1983. A plant DNA minipreparation: Version II. Plant Mol. Biol. Rep. 1:19-21.

De Marchi, B. R., Marubayashi, J. M., Favara, G. M., Yuki, V. A., Watanabe, L. F. M., Barbosa, L. F., Pavan, M. A., and Krause-Sakate, R. 2017. Comparative transmission of five viruses by Bemisia tabaci NW2 and MEAM1. Trop. Plant Pathol. 42:495-499.

Duffy, S., and Holmes, E. C. 2009. Validation of high rates of nucleotide substitution in geminiviruses: Phylogenetic evidence from East African cassava mosaic viruses. J. Gen. Virol. 90:1539-1547.

Duffy, S., Shackelton, L. A., and Holmes, E. C. 2008. Rates of evolutionary change in viruses: Patterns and determinants. Nat. Rev. Genet. 9:267-276.

Elena, S. F. 2017. Local adaptation of plant viruses: Lessons from experimental evolution. Mol. Ecol. 26:1711-1719.

Estévez de Jensen, C., Badillo-Vargas, I. E., Frantz, G., Mellinger, H. C., Turechek, W. W., Hutton, S. F., Funderburk, J. E., Naidu, R. A., and Adkins, S. 2017. First report of Tomato chlorotic spot virus in the non-solanaceous weeds erect spiderling (Boerhavia erecta), Asian spiderflower (Cleome viscosa), and sweet chili pepper (Capsicum chinense) in Puerto Rico. Plant Health Prog. 18:17-18. 
Evans, D., and Jeske, H. 1993. DNA B facilitates, but is not essential for, the spread of Abutilon mosaic virus in agroinoculated Nicotiana benthamiana. Virology 194:752-757.

Ferro, C., Silva, J., Xavier, C., Godinho, M., Lima, A., Mar, T., Lau, D., and Zerbini, F. M. 2017. The ever increasing diversity of begomoviruses infecting non-cultivated hosts: New species from Sida spp. and Leonurus sibiricus, plus two New World alphasatellites. Ann. Appl. Biol. 170: 204-218.

Fiallo-Olivé, E., Chirinos, D. T., Geraud-Pouey, F., and Navas-Castillo, J. 2017. Complete genome sequence of jacquemontia yellow vein virus, a novel begomovirus infecting Jacquemontia tamnifolia in Venezuela. Arch. Virol. 162:2463-2466.

Fontes, E., Gladfelter, H. J., Schaffer, R. L., Petty, I., and Hanley-Bowdoin, L. 1994. Geminivirus replication origins have a modular organization. Plant Cell 6:405-416.

Frischmuth, T., Roberts, S., von Arnim, A., and Stanley, J. 1993. Specificity of bipartite geminivirus movement proteins. Virology 196:666-673.

Galvao, R. M., Mariano, A. C., Luz, D. F., Alfenas, P. F., Andrade, E. C., Zerbini, F. M., Almeida, M. R., and Fontes, E. P. 2003. A naturally occurring recombinant DNA-A of a typical bipartite begomovirus does not require the cognate DNA-B to infect Nicotiana benthamiana systemically. J. Gen. Virol. 84:715-726.

Garrido-Ramirez, E., Sudarshana, M., and Gilbertson, R. L. 2000a. Bean golden yellow mosaic virus from Chiapas, Mexico: Characterization, pseudorecombination with other bean-infecting geminiviruses and germ plasm screening. Phytopathology 90:1224-1232.

Garrido-Ramirez, E., Sudarshana, M., Lucas, W., and Gilbertson, R. L. 2000b. Bean dwarf mosaic virus BV1 protein is a determinant of the hypersensitive response and avirulence in Phaseolus vulgaris. Mol. Plant-Microbe Interact. 13:1184-1194.

Gilbertson, R. L., Batuman, O., Webster, C. G., and Adkins, S. 2015. Role of the insect supervectors Bemisia tabaci and Frankliniella occidentalis in the emergence and global spread of plant viruses. Annu. Rev. Virol. 2: 67-93.

Gilbertson, R. L., Hidayat, S. H., Martinez, R. T., Leong, S. A., Faria, J. C., Morales, F., and Maxwell, D. P. 1991. Differentiation of bean-infecting geminiviruses by nucleic acid hybridization probes and aspects of bean golden mosaic in Brazil. Plant Dis. 75:336-342.

Gutierrez, C. 1999. Geminivirus DNA replication. Cell. Mol. Life Sci. 56: 313-329.

Hagen, C., Rojas, M. R., Sudarshana, M., Xoconostle-Cazares, B., Natwick, E., Turini, T., and Gilbertson, R. L. 2008. Biology and molecular characterization of Cucurbit leaf crumple virus, an emergent cucurbitinfecting begomovirus in the Imperial Valley of California. Plant Dis. 92: 781-793.

Hajdukiewicz, P., Svab, Z., and Maliga, P. 1994. The small, versatile pPZP family of Agrobacterium binary vectors for plant transformation. Plant Mol. Biol. 25:989-994.

Hanley-Bowdoin, L., Bejarano, E. R., Robertson, D., and Mansoor, S. 2013. Geminiviruses: Masters at redirecting and reprogramming plant processes. Nat. Rev. Microbiol. 11:777-788.

Hanley-Bowdoin, L., Settlage, S. B., Orozco, B. M., Nagar, S., and Robertson, D. 1999. Geminiviruses: Models for plant DNA replication, transcription, and cell cycle regulation. Crit. Rev. Plant Sci. 18:71-106.

Hernández-Zepeda, C., Idris, A. M., Carnevali, G., Brown, J. K., and Moreno-Valenzuela, O. A. 2007a. Preliminary identification and coat protein gene phylogenetic relationships of begomoviruses associated with native flora and cultivated plants from the Yucatan Peninsula of Mexico. Virus Genes 35:825-833.

Hernández-Zepeda, C., Idris, A. M., Carnevali, G., Brown, J. K., and Moreno-Valenzuela, O. A. 2007b. Molecular characterization and phylogenetic relationships of two new bipartite begomovirus infecting malvaceous plants in Yucatan, Mexico. Virus Genes 35:369-377.

Holmes, E. C. 2009. The evolutionary genetics of emerging viruses. Annu. Rev. Ecol. Evol. Syst. 40:353-372.

Hou, Y.-M., Paplomatas, E. J., and Gilbertson, R. L. 1998. Host adaptation and replication properties of two bipartite geminiviruses and their pseudorecombinants. Mol. Plant-Microbe Interact. 11:208-217

Huson, D. H., and Bryant, D. 2005. Application of phylogenetic networks in evolutionary studies. Mol. Biol. Evol. 23:254-267.

Idris, A. M., Al-Saleh, M., Zakri, A., and Brown, J. K. 2019. Minimal genomic variability in Merremia mosaic virus isolates endemic in Merremia spp. and cultivated tomato in Puerto Rico. Virus Dis. 30:84-94.

Ingham, D. J., Pascal, E., and Lazarowitz, S. G. 1995. Both bipartite geminivirus movement proteins define viral host range, but only BL1 determines viral pathogenicity. Virology 207:191-204.

Inoue-Nagata, A. K., Albuquerque, L. C., Rocha, W. B., and Nagata, T. 2004. A simple method for cloning the complete begomovirus genome using the bacteriophage $\varphi 29$ DNA polymerase. J. Virol. Methods 116:209-211.
Inoue-Nagata, A. K., Lima, M. F., and Gilbertson, R. L. 2016. A review of geminivirus diseases in vegetables and other crops in Brazil: Current status and approaches for management. Hortic. Bras. 34:8-18.

Jones, R. A. 2009. Plant virus emergence and evolution: Origins, new encounter scenarios, factors driving emergence, effects of changing world conditions, and prospects for control. Virus Res. 141:113-130.

Klinkenberg, F. A., and Stanley, J. 1990. Encapsidation and spread of African cassava mosaic virus DNA-A in the absence of DNA-B when agroinoculated to Nicotiana benthamiana. J. Gen. Virol. 71:1409-1412.

Kon, T., Rojas, M. R., Abdourhamane, I. K., and Gilbertson, R. L. 2009. Roles and interactions of begomoviruses and satellite DNAs associated with okra leaf curl disease in Mali, West Africa. J. Gen. Virol. 90:1001-1013.

Kumar, S., Stecher, G., and Tamura, K. 2016. MEGA7: Molecular Evolutionary Genetics Analysis version 7.0 for bigger datasets. Mol. Biol. Evol. 33:1870-1874

Lima, A. T., Sobrinho, R. R., Gonzalez-Aguilera, J., Rocha, C. S., Silva, S. J., Xavier, C. A., Silva, F. N., Duffy, S., and Zerbini, F. M. 2013. Synonymous site variation due to recombination explains higher genetic variability in begomovirus populations infecting non-cultivated hosts. J. Gen. Virol. 94: 418-431.

Mar, T. B., Xavier, C. A. D., Lima, A. T. M., Nogueira, A. M., Silva, J. C. F., Ramos-Sobrinho, R., Lau, D., and Zerbini, F. M. 2017. Genetic variability and population structure of the New World begomovirus Euphorbia yellow mosaic virus. J. Gen. Virol. 98:1537-1551.

Martin, D. P., Murrell, B., Golden, M., Khoosal, A., and Muhire, B. 2015. RDP4: Detection and analysis of recombination patterns in virus genomes. Virus Evol. 1:vev003.

Martínez-Ayala, A., Sánchez-Campos, S., Cáceres, F., Aragón-Caballero, L., Navas-Castillo, J., and Moriones, E. 2014. Characterisation and genetic diversity of pepper leafroll virus, a new bipartite begomovirus infecting pepper, bean and tomato in Peru. Ann. Appl. Biol. 164:62-72.

Maruthi, M., Manjunatha, B., Rekha, A., Govindappa, M., Colvin, J., and Muniyappa, V. 2006. Dolichos yellow mosaic virus belongs to a distinct lineage of Old World begomoviruses; its biological and molecular properties. Ann. Appl. Biol. 149:187-195.

Melgarejo, T. A., Kon, T., and Gilbertson, R. L. 2015. Molecular and biological characterization of distinct strains of Jatropha mosaic virus from the Dominican Republic reveal a potential to infect crop plants. Phytopathology 105:141-153.

Melgarejo, T. A., Kon, T., Rojas, M. R., Paz-Carrasco, L., Zerbini, F. M., and Gilbertson, R. L. 2013. Characterization of a New World monopartite begomovirus causing leaf curl disease of tomato in Ecuador and Peru reveals a new direction in geminivirus evolution. J. Virol. 87:5397-5413.

Melo, A. M., Silva, S. J., Ramos-Sobrinho, R., Ferro, M. M., Assunção, I. P., and Lima, G. S. 2016. Cnidoscolus mosaic leaf deformation virus: A novel begomovirus infecting euphorbiaceous plants in Brazil. Arch. Virol. 161: 2605-2608.

Moury, B., Fabre, F., Hébrard, E., and Froissart, R. 2017. Determinants of host species range in plant viruses. J. Gen. Virol. 98:862-873.

Muhire, B. M., Varsani, A., and Martin, D. P. 2014. SDT: A virus classification tool based on pairwise sequence alignment and identity calculation. PLoS One 9:e108277.

Nascimento, L. D., Silva, S. J., Sobrinho, R. R., Ferro, M. M., Oliveira, M. H., Zerbini, F. M., Assunção, I. P., and Lima, G. S. 2016. Complete nucleotide sequence of a new begomovirus infecting a malvaceous weed in Brazil. Arch. Virol. 161:1735-1738.

Noueiry, A. O., Lucas, W. J., and Gilbertson, R. L. 1994. Two proteins of a plant DNA virus coordinate nuclear and plasmodesmal transport. Cell 76: 925-932.

Passos, L. S., Rodrigues, J. S., Soares, É. C. S., Silva, J. P., Zerbini, F. M., Araújo, A. S. F., and Beserra, J. E. A. 2017. Complete genome sequence of a new bipartite begomovirus infecting Macroptilium lathyroides in Brazil. Arch. Virol. 162:3551-3554.

Petty, I. T., Carter, S. C., Morra, M. R., Jeffrey, J. L., and Olivey, H. E. 2000. Bipartite geminivirus host adaptation determined cooperatively by coding and noncoding sequences of the genome. Virology 277:429-438.

Pinto, V. B., Silva, J. P., Fiallo-Olivé, E., Navas-Castillo, J., and Zerbini, F. M. 2016. Novel begomoviruses recovered from Pavonia sp. in Brazil. Arch. Virol. 161:735-739.

Pramesh, D., Mandal, B., Phaneendra, C., and Muniyappa, V. 2013. Host range and genetic diversity of croton yellow vein mosaic virus, a weed-infecting monopartite begomovirus causing leaf curl disease in tomato. Arch. Virol. 158:531-542.

Qazi, J., Ilyas, M., Mansoor, S., and Briddon, R. W. 2007. Legume yellow mosaic viruses: Genetically isolated begomoviruses. Mol. Plant Pathol. 8: 343-348.

Rocha, C. S., Castillo-Urquiza, G. P., Lima, A. T., Silva, F. N., Xavier, C. A., Hora-Júnior, B. T., Beserra-Júnior, J. E., Malta, A. W., Martin, D. P., and Varsani, A. 2013. Brazilian begomovirus populations are highly 
recombinant, rapidly evolving, and segregated based on geographical location. J. Virol. 87:5784-5799.

Rojas, M. R., Gilbertson, R. L., Russell, D. R., and Maxwell, D. P. 1993. Use of degenerate primers in the polymerase chain reaction to detect whiteflytransmitted geminiviruses. Plant Dis. 77:340-347.

Rojas, M. R., Hagen, C., Lucas, W. J., and Gilbertson, R. L. 2005. Exploiting chinks in the plant's armor: Evolution and emergence of geminiviruses. Annu. Rev. Phytopathol. 43:361-394.

Rojas, M. R., Macedo, M. A., Maliano, M. R., Soto-Aguilar, M., Souza, J. O., Briddon, R. W., Kenyon, L., Rivera-Bustamante, R. F., Zerbini, F. M., Adkins, S., Legg, J. P., Kvarnheden, A., Wintermantel, W. M., Sudarshana, M. R., Peterschmitt, M., Lapidot, M., Martin, D. P., Moriones, E., Inoue-Nagata, A. K., and Gilbertson, L. R. 2018. World management of geminiviruses. Annu. Rev. Phytopathol. 56:637-677.

Romay, G., Chirinos, D. T., Geraud-Pouey, F., Torres, M., and Bragard, C. 2016. First report of Potato yellow mosaic virus infecting Solanum americanum in Venezuela. New Dis. Rep. 34:20.

Ronquist, F., Teslenko, M., Van Der Mark, P., Ayres, D. L., Darling, A., Höhna, S., Larget, B., Liu, L., Suchard, M. A., and Huelsenbeck, J. P. 2012. MrBayes 3.2: Efficient Bayesian phylogenetic inference and model choice across a large model space. Syst. Biol. 61:539-542.

Sánchez-Campos, S., Martínez-Ayala, A., Márquez-Martín, B., Aragón-Caballero, L., Navas-Castillo, J., and Moriones, E. 2013. Fulfilling Koch's postulates confirms the monopartite nature of tomato leaf deformation virus: A begomovirus native to the New World. Virus Res. 173:286-293.

Sanderfoot, A. A., and Lazarowitz, S. G. 1995. Cooperation in viral movement: The geminivirus BL1 movement protein interacts with BR1 and redirects it from the nucleus to the cell periphery. Plant Cell 7:1185-1194.

Santos, B. M., Gilreath, J. P., Lugo, M. L., and Rivera, L. E. 2008. Managing weeds with drip-applied herbicides in tomato. Crop Prot. 27:101-103.

Silva, S. J. C., Castillo-Urquiza, G. P., Hora-Júnior, B. T., Assunção, I. P., Lima, G. S. A., Pio-Ribeiro, G., Mizubuti, E. S. G., and Zerbini, F. M. 2012. Species diversity, phylogeny and genetic variability of begomovirus populations infecting leguminous weeds in northeastern Brazil. Plant Pathol. 61:457-467.

Sobrinho, R. R., Xavier, C. A. D., de Barros Pereira, H. M., de Andrade Lima, G. S., Assunção, I. P., Mizubuti, E. S. G., Duffy, S., and Zerbini, F. M. 2014. Contrasting genetic structure between two begomoviruses infecting the same leguminous hosts. J. Gen. Virol. 95:2540-2552.
Stewart, C., Kon, T., Rojas, M. R., Graham, A., Martin, D., Gilbertson, R. L., and Roye, M. R. 2014. The molecular characterisation of a Sida-infecting begomovirus from Jamaica. Arch. Virol. 159:375-378.

Struwig, M., and Siebert, S. 2013. A taxonomic revision of Boerhavia (Nyctaginaceae) in southern Africa. S. Afr. J. Bot. 86:116-134.

Tahir, M., Amin, I., Haider, M. S., Mansoor, S., and Briddon, R. W. 2015. Ageratum enation virus-A begomovirus of weeds with the potential to infect crops. Viruses 7:647-665.

Tavares, S., Ramos-Sobrinho, R., González-Aguilera, J., Lima, G., Assunção, I., and Zerbini, F. M. 2012. Further molecular characterization of weedassociated begomoviruses in Brazil with an emphasis on Sida spp. Planta Daninha 30:305-315.

Van Zant, M. K., Diesburg, K., and Lightfoot, D. A. 2018. Mirabilis expansa growth, yield, and quality traits: First US field trials for an ancient, endangered, Andean crop. Atlas J. Biol. 2018:551-574.

Varsani, A., Roumagnac, P., Fuchs, M., Navas-Castillo, J., Moriones, E., Idris, A., Briddon, R. W., Rivera-Bustamante, R., Zerbini, F. M., and Martin, D. P. 2017. Capulavirus and Grablovirus: Two new genera in the family Geminiviridae. Arch. Virol. 162:1819-1831.

Wise, A. A., Liu, Z., and Binns, A. N. 2006. Three methods for the introduction of foreign DNA into Agrobacterium. Methods Mol. Biol. 343:43-54.

Zaidi, S. S. E. A., Martin, D. P., Amin, I., Farooq, M., and Mansoor, S. 2017. Tomato leaf curl New Delhi virus: A widespread bipartite begomovirus in the territory of monopartite begomoviruses. Mol. Plant Pathol. 18: 901-911.

Zerbini, F. M., Briddon, R. W., Idris, A., Martin, D. P., Moriones, E., Navas-Castillo, J., Rivera-Bustamante, R., Roumagnac, P., and Varsani, A. 2017. ICTV virus taxonomy profile: Geminiviridae. J. Gen. Virol. 98:131-133.

Zhou, X. 2013. Advances in understanding begomovirus satellites. Annu. Rev. Phytopathol. 51:357-381.

Zhou, Y.-C., Garrido-Ramirez, E., Sudarshana, M., Yendluri, S., and Gilbertson, R. L. 2007. The N-terminus of the begomovirus nuclear shuttle protein (BV1) determines virulence or avirulence in Phaseolus vulgaris. Mol. Plant-Microbe Interact. 20:1523-1534.

Zhou, Y.-C., Noussourou, M., Kon, T., Rojas, M. R., Jiang, H., Chen, L.-F., Gamby, K., Foster, R., and Gilbertson, R. L. 2008. Evidence of local evolution of tomato-infecting begomovirus species in West Africa: Characterization of tomato leaf curl Mali virus and tomato yellow leaf crumple virus from Mali. Arch. Virol. 153:693-706. 